\title{
Comparison of Serum Lipoprotein(a) Distribution and its Correlates among Black and White Populations
}

\author{
PASCAL BOVET," MARTIN RICKENBACH," VINCENT WIETLISBACH," WALTER RIESEN,** \\ CONRAD SHAMLAYE, ${ }^{\dagger}$ ROGER DARIOLI ${ }^{\ddagger}$ AND BERNARD BURNAND*
}

\begin{abstract}
Bovet P (Clınical Epidemiology Unit, Institute of Social and Preventive Medicine, University of Lausanne, Bugnon 17. CH-1005 Lausanne, Switzerland), Rickenbach M, Wietlisbach V, Riesen W, Shamlaye C, Darioli R and Burnand B. Comparison of lipoprotein(a) distribution and its correlates among black and white populations. Internationa/ Journa/ of Epidemiology 1994; 23: 20-27.

Background Epidemiological data on serum lipoprotein(a) (Lp(a)), a presumably strong risk factor for coronary artery disease in White populations, has mostly been derived, in Black populations, from small samples. This study compares the distribution and the determinants of serum Lp(a) in Blacks and in Whites using large representative samples and the same methods in both populations.

Methods The distribution and the correlates of serum Lpla) were investigated in population-based samples of 701 Blacks in the Seychelles and 634 Whites in Switzerland, aged 25-64 years. Serum Lp(a) was quantified using a commercial immunoradiometric assay.

Results The distribution of serum $L p(a)$ was similarly skewed in both ethnic groups, but median Lp(a) concentration was about twofold higher in Blacks $(210 \mathrm{mg} / \mathrm{l})$ compared to Whites $(100 \mathrm{mg} / \mathrm{ll})$. The proportions of individuals with elevated serum $L p(a)(>300 \mathrm{mg} / \mathrm{l})$ was about $50 \%$ higher in Blacks $(37.5 \%)$ than in Whites $(25.2 \%)$. In both ethnic groups, serum Lp(a) was found to correlate with total cholesterol, LDL-cholesterol and apoprotein B but not with HDLcholesterol, alcohol intake, smoking, and body mass index. The variance in serum Lp(a) concentration explained by any combination of these factors was smaller than $5.3 \%$ in the two populations.

Conclusions The measured factors did not explain the higher levels of serum Lp(a) found in Blacks compared to Whites. These findings are consistent with the hypothesis that genetıc factors account for much of the variation of serum $L p(a)$ in both populations.
\end{abstract}

Lipoprotein(a) $(\mathrm{Lp}(\mathrm{a}))$ is a cholesterol-rich lipoprotein found in human serum that resembles low-density lipoprotein (LDL) but contains in addition apolipoprotein(a) (apo(a)) which has close structural homology with plasminogen. ${ }^{1,2} \mathrm{~A}$ single gene appears to determine a size polymorphism of apo(a) which relates to serum $\mathrm{Lp}(\mathrm{a})$ concentration and family studies indicate that more than $90 \%$ of the interindividual variation in serum $L p(a)$ is determined by this gene encoding apo(a). ${ }^{3.4}$ Serum $L p(a)$ concentrations are fairly constant throughout an individual's life but vary between individuals over a wide range (from

\footnotetext{
- Clinical Epidemiology Unt, Institute of Social and Preventive Medicine, University of Lausanne, Bugnon 17, CH-1005 Lausanne. Switzerland.

** Institute of Clinical Chemistry and Hematology, Canton Hospital,

St Gallen, Switzerland.

${ }^{t}$ Unit of Epidemiology and Research, Ministry of Health, Victoria, Seychelles.

† Lipids Unit, University Medical Polıclinic, Lausanne, Switzerland.
}

$<0.1$ to $>4000 \mathrm{mg} / \mathrm{l}$ ) with a highly skewed distribution, at least in White (Caucasian) populations. ${ }^{2,5-7}$ Although its function is not established, $L p(a)$ has thrombotic and atherogenic properties. ${ }^{8}$ Indeed, serum Lp(a) is currently gaining much attention as a quantitative, genetically controlled, independent risk factor for prediction of coronary artery disease in Caucasian populations. ${ }^{9-13}$ However, the role of serum $\mathrm{Lp}(\mathrm{a})$ as a risk factor for coronary artery disease in Blacks is controversial. ${ }^{14-16}$

Distribution of serum $L p(a)$ has been repeatedly examined in White populations ${ }^{2.5-7}$ although only a few studies included population-based data ${ }^{17}$ and not all of them provided the appropriate distribution measures, such as medians and percentiles, needed for comparison between populations. In contrast, few studies have examined serum $L p(a)$ distribution in Blacks and most of them included small samples and were not designed to be representative of the whole population. When comparing serum $\mathrm{Lp}$ (a) distribution 
in Blacks and in Whites, it has been reported that $\mathrm{Lp}$ (a) was markedly more Gaussian in Blacks than in Whites, ${ }^{2,18-21}$ a finding that is not supported by our data.

This report provides data on serum Lp(a) distribution in the Black population of the Seychelles and in the White population of Switzerland. Large population-based samples and the same study designs and laboratory methods were used for both populations, so that valid comparisons can be drawn between these two ethnically different populations. The relation of serum $L p(a)$ to other factors was also examined in the two populations.

\section{METHODS}

\section{Study Populations}

The Seychelles Islands are located in the Indian Ocean, approximately $1800 \mathrm{~km}$ east of Kenya and $1800 \mathrm{~km}$ north of Mauritius, and are now considered a middlelevel income country with an annual gross national product per capita of $>$ US $\$ 3500$. The population of the Seychelles consists of a mixed rural-urban population. The Seychelles had no indigenous population until 1770 when French settlers arrived, joined later by a large number of people from the eastern coast of Africa and a small number of English, Indians and Chinese. $^{22}$

In the Seychelles, cardiovascular risk factors in the population were determined in 1989 within the framework of the Seychelles Cardiovascular Disease Study. ${ }^{23}$ The population screened was the population of Mahe Island, which accounts for approximately $90 \%$ of the total population of the Seychelles $(66370)$. A random sample of the population aged 25-64 years, stratified by sex and age, was drawn; $1081(86.4 \%)$ individuals took part in the survey out of 1251 eligible. This study included only individuals who were of African descent (730) based on external anthropomorphic features as assessed by the same investigator (PB) throughout the whole survey. Serum $L p(a)$ could not be determined in 29 individuals due to shortage of serum, hence data from 701 individuals were analysed. Detailed sampling procedures, laboratory methods, and sociodemographic data have been reported previously. ${ }^{24}$

In Switzerland, a similar population survey was carried out in 1988-1989 within the framework of the WHO MONICA project. The sampling procedure has been previously reported in detail. ${ }^{25}$ Briefly, a twostage sampling procedure was used to obtain a representative sample of the adult population. A participation rate of $65 \%$ was obtained among the 3210 individuals eligible to take part in the survey in the cantons of Vaud and Fribourg. One hundred serum samples were then randomly selected to determine serum $L p(a)$ in each group stratified for sex- and 10 -year age group. This study was further restricted to Swiss nationals and only data from people aged 25-64 years were used in the comparisons with the Seychelles. Hence, data from 634 individuals were analysed.

\section{Laboratory Methods}

Frozen fasting (Seychelles) and non-fasting (Switzerland) sera were analysed in Switzerland less than 18 months after blood collection. Serum $L p(a)$ was measured in one single laboratory using a commercial solid phase two-site immunoradiometric assay (Apo(a) RIA, Pharmacia, Uppsala, Sweden) similar to the one reported by Albers et al. ${ }^{26}$ The assay was sensitive in the concentration range $0.2 \mathrm{U} / 1$ to $\leqslant 8000 \mathrm{U} / 1$ which corresponds approximately to mass units $0.1 \mathrm{mg} / \mathrm{l}$ to $\leqslant 5600 \mathrm{mg} / \mathrm{l}$. The day to day variation coefficient was less than $6 \%$. No measurable cross-reaction occurred with serum plasminogen or apoprotein B (apoB). Serum total cholesterol was determined enzymaticaily (Roche, Basel, Switzerland). Serum high density lipoprotein (HDL) cholesterol was similarly quantified after precipitation of the apoB-containing lipoproteins with phosphotungstate and magnesium chloride (Roche). Serum apoproteins A-I (apoA) and apoB were quantified by immunoturbidimetry (Turbitimer ${ }^{\text {TM }}$ System, Behring, Marburg, Germany). Serum low density lipoprotein (LDL) cholesterol was calculated (Seychelles) with the Friedewald formula and measured (Switzerland) after precipitation with an amphiphilic polymer (Bio-Mérieux, Lyons, France).

\section{Anthropometric and Lifestyle Variables}

Blood pressure, weight and height were measured according to the WHO MONICA study protocol ${ }^{27}$ and data on smoking were obtained from a questionnaire. Body mass index was used as an index of obesity (weight $(\mathrm{kg}) / \mathrm{height}(\mathrm{m})^{2}$ ). Alcohol intake was calculated as grams of pure alcohol per day based on a detailed questionnaire on alcohol habits (Seychelles) and dichotomized (consumption of alcohol versus no consumption) according to the reported consumption on the previous day (Switzerland).

\section{Statistical Analysis}

Normally distributed variables and categorical variables were compared using $t$ - and $\chi^{2}$ tests, respectively. Because serum $L p(a)$ was not normally distributed, the Wilcoxon rank-sum test was used to compare medians between sex and race groups. The Mantel-Haenszel test was used to evaluate the association between ethnicity and an elevated level of serum 
Lp(a). Multiple logistic regression was used to investigate the association between ethnicity and an elevated serum $L p(a)$ after adjustment for selected variables. The univariate relation of serum $L p(a)$ to other variables was examined using the non-parametric Spearman's correlation coefficients within each of the four race and sex groups. Multivariate linear regression was used to explore the independent correlates of serum $\mathrm{Lp}(\mathrm{a})$ in Blacks and in Whites separately. Explanatory variables were chosen on the basis of previously demonstrated associations with $\mathrm{Lp}(\mathrm{a})$ or because of known relations with blood lipids or lipoproteins. Because of the skewed distribution of serum $L p(a)$, the natural logarithm was used when fitting models.

\section{RESULTS}

\section{Cardiovascular Risk Factors}

Race- and sex-specific levels of cardiovascular risk factors are summarized in Table 1. Details of the cardiovascular risk factors distribution have been published elsewhere. ${ }^{23,28,29}$ According to the study design, the four sex and race groups were similar in age in both countries. Total cholesterol, LDL-cholesterol, and apoB were higher in Whites compared to Blacks. HDL-cholesterol and apoA were higher in men compared to women in the Seychelles but higher in women compared to men in Switzerland. Body mass index was higher in women compared to men in the Seychelles but higher in men than in women in Switzerland. Dif- ferent proportions of smokers were found in men $(55 \%)$ and in women $(11 \%)$ in the Seychelles while more balanced proportions were found in men $(36 \%)$ and in women $(25 \%)$ in Switzerland. High blood pressure was more prevalent in men compared to women in the two countries and more prevalent in the Seychelles compared to Switzerland.

The unusual higher HDL-cholesterol and apoA levels in men compared to women in the Seychelles can mostly be accounted for by the very high consumption of alcohol by men ${ }^{30}$ and the much higher prevalence of obesity in women than in men ${ }^{31}$ (data not shown). A prevalence of diabetes of $7 \%$ in male and in female Seychellois aged $35-64^{31}$ is comparable to the prevalence in Switzerland. Based on clinical experience, hormonal contraception is probably not much less frequently used in the Seychelles than in Switzerland; almost no Seychellois postmenopausal women received replacement hormonal therapy whereas the figure is estimated to be around $10-15 \%$ in Switzerland.

\section{Distribution of Serum $L p(a)$}

Race-, sex-, and age-specific untransformed mean values and selected percentiles of serum $L p(a)$ are shown in Table 2. Sex- and age-specific median Lp(a) concentrations were approximately twofold higher in Blacks compared to Whites. No clear pattern between serum $\mathrm{Lp}(\mathrm{a})$ and age was observed in Black and in White men. In contrast, serum $L p(a)$ increased

TABLE 1 Mean values and proportions of some cardiovascular risk factors in Seychellois Blacks and Swiss Whiles aged 25-64 years, Seychelles Cardiovascular Disease Study 1989 and MONICA Vaud/t ribourg 1988-1989

\begin{tabular}{|c|c|c|c|c|}
\hline \multirow[b]{2}{*}{ No. } & \multicolumn{2}{|c|}{ Seychellois Blacks } & \multicolumn{2}{|c|}{ Swiss Whites } \\
\hline & $\begin{array}{c}\text { Men } \\
328\end{array}$ & $\begin{array}{c}\text { Women } \\
371\end{array}$ & $\begin{array}{c}\text { Men } \\
300\end{array}$ & $\begin{array}{c}\text { Women } \\
334\end{array}$ \\
\hline Age (years) & $45.3 \pm 11.2^{\mathrm{a}}$ & $45.5 \pm 11.6$ & $43.8 \pm 11.8$ & $44.5 \pm 11.8$ \\
\hline Total cholesterol $(\mathrm{mmol} / \mathrm{l})$ & $4.94 \pm 1.08$ & $535 \pm 1.20$ & $6.37 \pm 1.14$ & $6.28 \pm 1.36$ \\
\hline LDL-cholesterol (mmol/l) & $2.91 \pm 1.12$ & $3.54 \pm 1.16$ & $4.12 \pm 0.92$ & $3.87 \pm 1.09$ \\
\hline HDL-cholesterol (mmol/l) & $1.52 \pm 0.56$ & $1.39 \pm 0.37$ & $1.28 \pm 0.32$ & $1.54 \pm 0.39$ \\
\hline Apoprotein A-I (mg/l) & $1.50 \pm 0.45$ & $1.39 \pm 0.32$ & $1.26 \pm 0.21$ & $1.42 \pm 0.22$ \\
\hline Apoprotein B (mg/l) & $1.01 \pm 0.35$ & $1.13 \pm 0.37$ & $1.30 \pm 0.33$ & $1.17 \pm 0.32$ \\
\hline Body mass index $\left(\mathrm{kg} / \mathrm{m}^{2}\right)$ & $23.2 \pm 3.90$ & $26.9 \pm 6.00$ & $25.5 \pm 3.40$ & $24.7 \pm 4.50$ \\
\hline Cigarette smoking $(\%)$ & 55.3 & 11.0 & 36.3 & 24.6 , \\
\hline Cigarettes per day per smoker & $11.1 \pm 7.50$ & $6.8 \pm 6.4$ & $23.8 \pm 11.5$ & $16.3 \pm 7.30$ \\
\hline Systolic blood pressure $(\mathrm{mm} \mathrm{Hg})$ & $136 \pm 25$ & $132 \pm 24$ & $131 \pm 15$ & $125 \pm 18$ \\
\hline Diasiolic blood pressure $(\mathrm{mm} \mathrm{Hg})$ & $89 \pm 15$ & $85 \pm 15$ & $80 \pm 10$ & $75 \pm 9$ \\
\hline High blood pressure $(\%)^{b}$ & 33.7 & 27.1 & 14.3 & 11.1 \\
\hline
\end{tabular}

\footnotetext{
- Mean \pm standard deviation (details of the distnbution have been published elsewhere). ${ }^{23,28,29}$

${ }^{b}$ Systolic/diastolic blood pressure $\geqslant 160 / 95 \mathrm{~mm} \mathrm{Hg}$ or under antihypertensive treatment.
} 
TABLE 2 Mean values, standard deviarions, and percentiles of serum lipoprotein(a) in Seychellois Blacks and Swiss Whires by race, ser and age, Seychelles Cardiovascular Disease Study 1989 and MONICA Voud/Fribourg 1988-1989

\begin{tabular}{|c|c|c|c|c|c|c|c|c|}
\hline & \multirow[b]{2}{*}{ No. } & \multirow[b]{2}{*}{ Mean } & \multirow[b]{2}{*}{ SD" } & \multicolumn{5}{|c|}{ Percentiles } \\
\hline & & & & 10 & 25 & 50 & 75 & 90 \\
\hline & \multicolumn{8}{|c|}{ Seychellois Blacks } \\
\hline \multicolumn{9}{|c|}{ - } \\
\hline $25-34$ & 67 & 272 & 274 & 30 & 74 & 175 & 421 & 631 \\
\hline $35-44$ & 80 & 392 & 466 & 39 & 87 & 236 & 571 & 814 \\
\hline $45-54$ & 93 & 332 & 467 & 29 & 54 & 182 & 380 & 801 \\
\hline $55-64$ & 89 & 391 & 398 & 32 & 93 & 221 & 574 & 950 \\
\hline Total & 329 & 350 & 414 & 31 & 76 & 214 & 521 & 807 \\
\hline \multicolumn{9}{|l|}{ Women } \\
\hline $25-34$ & 73 & 359 & 433 & 37 & 120 & 213 & 509 & 799 \\
\hline $35-44$ & 97 & 261 & 277 & 37 & 77 & 175 & 334 & 599 \\
\hline $45-54$ & 93 & 358 & 458 & 51 & 95 & 193 & 450 & 1012 \\
\hline $55-64$ & 109 & 463 & 630 & 44 & 134 & 286 & $\$ 37$ & 1170 \\
\hline \multirow[t]{2}{*}{ Total } & 372 & 364 & 479 & 42 & 94 & 208 & 457 & 812 \\
\hline & \multicolumn{8}{|c|}{ Swiss Whites } \\
\hline \multicolumn{9}{|l|}{ Men } \\
\hline $25-34$ & 78 & 261 & 487 & 20 & 31 & 71 & 221 & 679 \\
\hline $35-44$ & 81 & 262 & 448 & 18 & 31 & 77 & 316 & 835 \\
\hline $45-54$ & 65 & 298 & 529 & 19 & 45 & 82 & 259 & 927 \\
\hline $55-64$ & 76 & 219 & 328 & 21 & 35 & 98 & 232 & 571 \\
\hline Total & 300 & 259 & 541 & 19 & 32 & 82 & 251 & 782 \\
\hline \multicolumn{9}{|l|}{ Women } \\
\hline $25-34$ & 82 & 234 & 345 & 24 & 36 & 87 & 279 & 637 \\
\hline $35-44$ & 85 & 241 & 308 & 20 & 37 & 105 & 394 & 688 \\
\hline $45-54$ & 84 & 259 & 329 & 28 & 53 & 127 & 399 & 626 \\
\hline $55-64$ & 83 & 261 & 306 & 21 & 66 & 145 & 348 & 655 \\
\hline Total & 334 & 249 & 321 & 23 & 46 & 114 & 347 & 637 \\
\hline
\end{tabular}

- Standard deviation.

monotonically between 25 and 64 years in White women and a substantial increase occurred in the age group 55-64 in Black women. Median serum Lp(a) was weakly but significantly higher in women than in men in Switzerland (114 versus $82 \mathrm{mg} / \mathrm{l} ; P=0.024$ ) while no difference was observed in the Seychelles (208 versus $214 \mathrm{mg} / \mathrm{l}$ ), respectively; $P=0.641$ ). Median serum $\mathrm{Lp}(\mathrm{a})$ was higher in Blacks than in Whites $(210$ versus $100 \mathrm{mg} / 1 ; P=<0.001$ ). Serum $\mathrm{Lp}(\mathrm{a})$ values corresponding to the upper percentiles tended to increase with age in Blacks but not in Whites.

The distribution of serum Lp(a) was highly positively skewed in the two populations (skewness in Blacks/Whites: 3.42/3.47) (Figure 1) and could be fairly well normalized through a natural logarithm transformation (resulting skewness in Black/Whites:
$-0.02 / 0.04)$. Serum $L p(a)$ mean values calculated from the $\log _{e}$ scale were $184 \pm 3.3 / 198 \pm 3.2 \mathrm{mg} / \mathrm{l}$ in male/female Seychellois and $94 \pm 1.6 / 119 \pm 3.5 \mathrm{mg} / 1$ in male/female Swiss.

Figure 2 indicates the proportions of individuals with serum $L p(a)$ above selected threshold values in the range, $100-1000 \mathrm{mg} / \mathrm{l}$. Blacks had an approximately $50 \%$ greater risk than Whites of having serum Lp(a) above the selected thresholds (e.g. risk ratio for $L p(a)$ $>300 \mathrm{mg} / \mathrm{l}: 1.56 ; 95 \%$ confidence interval $[\mathrm{CI}]$ : $1.26-1.75)$.

We also performed multiple logistic regression to investigate the association between ethnicity and elevated serum $L p(a)$ levels after adjustment for selected variables (in this analysis serum $L p(a)$ $>300 \mathrm{mg} / \mathrm{l}$ was coded as 1 and $\mathrm{Lp}(\mathrm{a}) \leqslant 300$ as 0 ). The odds ratio (OR) for ethnicity without adjusment (OR $=1.78 ; 95 \% \mathrm{CI}: 1.40-2.26)$ did not change after adjustment for sex, age, body mass index, alcohol, and smoking habits (OR $=1.76 ; 95 \% \mathrm{CI}: 1.39-2.23)$ but substantially increased after additional adjustment for total cholesterol $(\mathrm{OR}=2.26 ; 95 \% \mathrm{Cl}: 1.75-2.93)$.

\section{Correlates of Serum Lp(a)}

Table 3 shows the Spearman's correlation coefficients between serum $\mathrm{Lp}(\mathrm{a})$ and selected variables. Total cholesterol and LDL-cholesterol were statistically significant univariate correlates of serum $L p(a)$ in the four race and sex groups and the magnitude of the correlation coefficients were similar in Blacks compared with Whites. ApoB correlated with serum $L p(a)$ in all race and sex groups except in Black women.

Multivariate linear regression models were carried out to identify independent predictors of serum $\mathrm{Lp}$ (a) in Blacks and in Whites separately. Total cholesterol, apoB and LDL-cholesterol may be considered as surrogates of cholesterol-rich lipoproteins and this is substantiated by Pearson's correlation coefficients between any combination of these three lipids ranging between 0.80 and 0.91 in both races. Therefore, multivariate models included either total cholesterol, apoB or LDL-cholesterol in addition to the other independent variables. Total cholesterol, apoB, or LDLcholesterol were significantly associated with the logarithm of serum $\mathrm{Lp}(\mathrm{a})$ in both Black and White populations after adjustment for the other variables (Table 4). The magnitude of the partial regression coefficients for total cholesterol, LDL-cholesterol, and apoB were similar in Blacks and in Whites, indicating that the effect of these lipids on serum $L p(a)$ was not modified by race. Sex was a weak but significant multivariate correlate of serum $L p(a)$ in Whites (regression coefficient $=-0.29$; standard error $=$ 


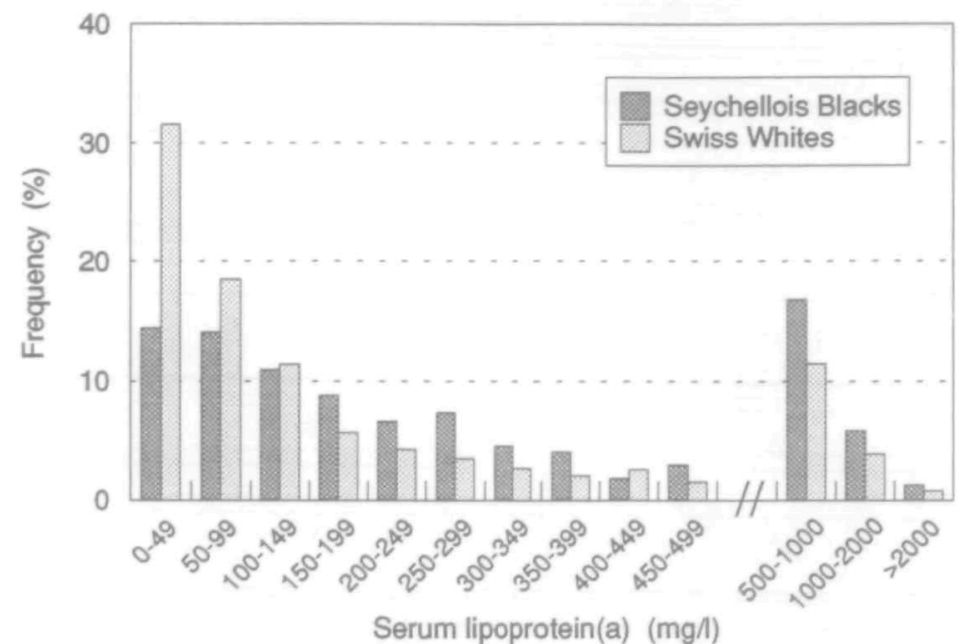

FIGURE 1 Frequency distribution of serum lipoprotein (a) in Seychellois Blacks and in Swiss Whites, Seychelles Cardiovascular Disease Study 1989 and MONICA Vaud/ Fribourg 1988-1989

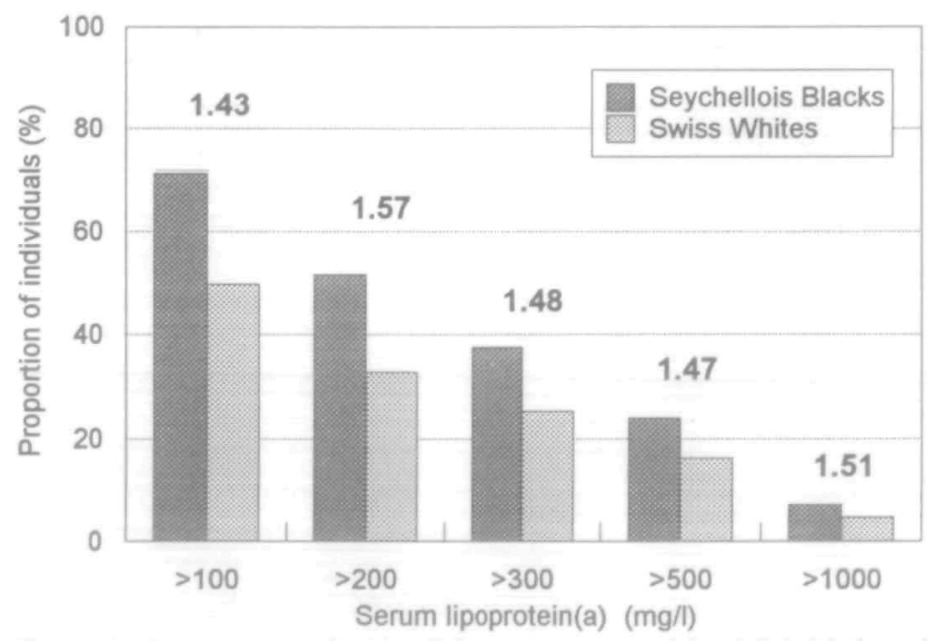

FIGURE 2 Proportions (and ratıos of these proporions) of Seychellois Blacks and Swiss Whites with serum lipoprotein(a) above selected thresholds, Seychelles Cardiovascular Disease Study 1989 and MONICA Vaud/Fribourg $1988-1989$

TABLE 3 Spearman's correlation coefficients between lipoprotein(a) and selected variables in Seychellois Blacks and Swiss Whites, Seychelles Cardiovascular Disease Study 1989 and MONICA Vaud/Fribourg 1988-1989

\begin{tabular}{|c|c|c|c|c|c|c|c|c|c|}
\hline & Total C & LDL-C & Apo B & HDL-C & Apo A-I & BMI & Alcohol & Cigarettes & Age \\
\hline \multicolumn{10}{|c|}{ Seychellois Blacks } \\
\hline Men & $0.15^{* *}$ & $0.22 * * *$ & $0.11^{*}$ & -0.01 & -0.06 & -0.01 & -0.03 & -0.01 & 0.06 \\
\hline Women & $0.23 * * *$ & $0.20^{* * *}$ & 0.06 & 0.06 & 0.08 & 0.01 & -0.04 & -0.02 & 0.07 \\
\hline \multicolumn{10}{|c|}{ Swiss Whites } \\
\hline Men & $0.17^{* *}$ & $0.21^{* * *}$ & $0.16^{* *}$ & -0.07 & -0.02 & 0.03 & 0.03 & -0.01 & 0.07 \\
\hline Women & $0.20^{* * *}$ & $0.24^{* * *}$ & $0.18^{* 6 *}$ & -0.04 & -0.03 & 0.08 & 0.01 & -0.05 & $0.11^{*}$ \\
\hline
\end{tabular}

a Total C: total cholesterol; LDL-C: LDL-cholesterol; HDL-C: HDL-cholesterol; BMI: body mass index.

*P<0.05; **P<0.01;***P<0.001. 
TABLE 4 Regression coefficients of lipids for the predicuion of logarithm of serum lipoprotein(a) in models including either total cholesterol, $L D L$-cholesterol, or apoprotein $B$ in addition to other independent variables, "Seychelles Cardiovascular Disease Siudy 1989 and MONICA Vaud/Fribourg 1988-1989

\begin{tabular}{|c|c|c|c|c|}
\hline & \multicolumn{2}{|c|}{$\begin{array}{l}\text { Seychellois Blacks } \\
\text { (No. = 701) }\end{array}$} & \multicolumn{2}{|c|}{$\begin{array}{l}\text { Swiss Whites } \\
\text { (No. = 634) }\end{array}$} \\
\hline & $\beta^{\mathrm{b}}$ & $\mathrm{SE}^{\mathrm{c}}$ & $\beta^{b}$ & $S E^{c}$ \\
\hline Total cholesterol (mmol/l) & 0.21 & $0.04^{* *}$ & 0.19 & $0.04^{* *}$ \\
\hline LDL-cholesterol $(\mathrm{mmol} / \mathrm{l})$ & 0.27 & $0.04 * *$ & 0.30 & $0.05^{* *}$ \\
\hline Apoprotein B (mg/l) & 0.34 & $0.14^{*}$ & 0.60 & $0.17^{* *}$ \\
\hline
\end{tabular}

a The other independent variables in all models were: age, sex, body mass index, drinking habıts, cigarette-smoking, HDL-cholesterol.

${ }^{b}$ Regression coefficient.

c Standard error.

${ }^{*} P<0.01 ; * * P<0.001$.

$0.12 ; P=0.014)$ but not in Blacks. HDL-cholesterol, age, body mass index, smoking, and alcohol did not correlate with serum $\mathrm{Lp}(\mathrm{a})$ in the two populations. No linear combination of the independent variables could explain more than $5.3 \%$ of the variance of the natural logarithm of serum $\mathrm{Lp}(\mathrm{a})$. The variance explained by all variables other than lipids (e.g. age, sex, body mass index, smoking, and alcohol) was smaller than $1 \%$ in the two populations.

\section{DISCUSSION}

Distribution of serum $\mathrm{Lp}(\mathrm{a})$ was highly asymmetrical in both Seychellois Black and Swiss White populations. The similar computed values of skewness in both populations and the fairly constant ratio of the proportions of Black and Whites with serum Lp(a) above a wide range of threshold values indicated that the distribution of serum $L p(a)$ was similarly skewed in Blacks and in Whites but that serum Lp(a) concentrations were shifted to higher values in Blacks. The distribution of serum $L p(a)$ in Black Seychellois differed substantially from the nearly Gaussian distribution of serum $L p(a)$ reported in small groups of Black Sudanese and Congolese $e^{2,19,20}$ but it was consistent with the distribution of serum $L p(a)$ found in a large population-based study of Black American children and adolescents. ${ }^{14}$ The approximately twofold higher median serum $\mathrm{Lp}(\mathrm{a})$ concentrations found in Seychellois Blacks compared to their Swiss White counterparts are however consistent with published data on the ethnic Black/White difference (Table 5). When reading the Table, medians should be preferred to means when comparing serum $L p(a)$ between dif- ferent populations because of the highly skewed nature of the distribution of serum $L p(a)$ and because some laboratory methods are not sensitive to very high values of serum $L p(a)$ (i.e. falsely low values of some measurements).

Ethnic difference in the distribution of serum $L p(a)$ raises public health concerns. Indeed, the risk for coronary artery disease in white populations was reported to be increased two to three times for serum $\mathrm{Lp}(\mathrm{a})>300 \mathrm{mg} / \mathrm{l},{ }^{11,13}$ although serum $\mathrm{Lp}(\mathrm{a})$ might not be such a strong risk factor for coronary artery disease in Blacks based on the limited data available to date. ${ }^{14-16}$ The finding, in our data, that serum $L p(a)$ values corresponding to the upper percentiles tended to increase with age in Blacks but not in Whites may be related to increased premature deaths in Whites but not in Blacks with high serum $L p(a)$, which may indirectly support the view that serum $L p(a)$ is a stronger risk factor in Whites than in Blacks. In our data, approximately $50 \%$ more Blacks than Whites had serum $L p(a)$ above threshold values in the range 100-1000 $\mathrm{mg} / \mathrm{l}$ (e.g. proportions of Blacks versus Whites with serum $L p(a) \quad>300 \mathrm{mg} / \mathrm{l}: \quad 38 \%$ versus $24 \%$ ). Moreover, the odds of having elevated serum $L p(a)$ in Blacks compared to Whites were further increased when analytical adjustment for equal levels of serum cholesterol was performed. From another standpoint, it has been stated from studies in Caucasian populations that the risk associated with elevated serum $L p(a)$ was dependent upon jointly elevated serum LDL. cholesterol. ${ }^{11.32}$ In this view, serum $L p(a)$ would be a weaker cardiovascular risk factor in the Seychelles considering that serum LDL-cholesterol was notably lower in the Seychelles than in Switzerland. Since serum $L p(a)$ may substantially differ in molecular structure across populations, ${ }^{20}$ further epidemiological studies will have to consider the possibility that the pathogenic action of $L p(a)$ might differ depending upon the $\mathrm{Lp}(\mathrm{a})$ species and establish the relative proatherogenic and prothrombotic roles of all $L p(a)$ species and their affiliated apo(a).

The correlates of serum $L p(a)$ in this study were similar in Blacks and in Whites and were generally consistent with those identified in other reports. Serum Lp(a) did not vary substantially with age in Black and in White men but increased serum $L p(a)$ levels were found in the older Black and White women. These findings are consistent with other reports in which serum $\mathrm{Lp}(\mathrm{a})$ concentration did not vary substantially with age $^{33}$ but was increased in postmenopausal women presumably due to the decrease in oestrogen levels. ${ }^{7,34,35}$ Total cholesterol, LDL-cholesterol and apoB were significant univariate and multivariate cor- 
TABLE S Ethnic (Black/White) difference in serum lipoprotein(a) in selected studies

\begin{tabular}{|c|c|c|c|c|c|c|c|c|}
\hline \multirow[t]{2}{*}{$\begin{array}{l}\text { Type of population } \\
\text { Country }\end{array}$} & \multirow[t]{2}{*}{ Ref. } & \multirow[t]{2}{*}{$\begin{array}{l}\text { Type of } \\
\text { assay }\end{array}$} & \multicolumn{2}{|c|}{$\begin{array}{l}\text { Subjects } \\
\text { (No.) }\end{array}$} & \multicolumn{2}{|c|}{$\begin{array}{l}\text { Mean Lp(a) } \\
(\mathbf{m g} / 1)\end{array}$} & \multicolumn{2}{|c|}{$\begin{array}{l}\text { Median Lp(a) } \\
(\mathbf{m g} / 1)\end{array}$} \\
\hline & & & Black & White & Black & White & Black & White \\
\hline $\begin{array}{l}\text { General population } \\
\text { Seychelles/Switzerland }\end{array}$ & - & RIA & 701 & 634 & 357 & 254 & 210 & 100 \\
\hline $\begin{array}{l}\text { Children aged } 8-17 \text { years } \\
\text { USA }\end{array}$ & 14 & ELISA & 885 & 1553 & 297 & 172 & 252 & 94 \\
\hline $\begin{array}{l}\text { Adult volunteers/health study } \\
\text { Nigeria/Belgium }\end{array}$ & 21 & ELISA & 60 & 60 & 177 & 160 & 147 & 74 \\
\hline $\begin{array}{l}\text { Employees } \\
\text { USA }\end{array}$ & 18 & EID & 105 & 134 & 313 & 170 & - & - \\
\hline $\begin{array}{l}\text { Healthy people } \\
\text { Congo/France }\end{array}$ & 19 & EID & 81 & 81 & 239 & 107 & 208 & 70 \\
\hline $\begin{array}{l}\text { Healthy people/population } \\
\text { Sudan/Iceland }\end{array}$ & 20 & EID & 105 & 184 & 457 & 135 & - & - \\
\hline
\end{tabular}

a RIA: radioimmunoassay; EID· electroimmunodıffusion; ELISA: enzyme-linked immunosorbent assay.

relates of serum $L p(a)$ in both Black and White populations. Ethnicity did not modify the relation of these lipids to $L p(a)$ as suggested by the similar magnitude of the regression coefficients found in Blacks and in Whites. Associations relating serum $\mathrm{Lp}$ (a) to LDL-cholesterol or total cholesterol have been noticed in other studies. ${ }^{7,36,37}$ The relation of these lipids to serum $L p(a)$ may however not be causal but rather reflect that measurements of serum total cholesterol, LDL-cholesterol, and apoB also measure cholesterol and apoB contained in the serum lipoprotein Lp(a). In our study, HDL-cholesterol, apoA, body mass index, smoking, alcohol consumption, and sex did not correlate with serum $L p(a)$ in the two populations, in agreement with studies reporting a lack of association between serum $\mathrm{Lp}(\mathrm{a})$ and body mass index, ${ }^{38}$ smoking, ${ }^{7}$ and alcohol. ${ }^{37}$ It is remarkable that any combination of the considered variables explained only very little $(<5.3 \%)$ of the variance of serum $\mathrm{Lp}(\mathrm{a})$ in the two populations. When comparing these two populations, White Swiss and Black Seychellois undoubtedly differ in many respects. However no additional environmental factors have been yet identified to correlate substantially with serum $L p(a)$ in populations and the ethnic difference in serum Lp(a) found in this study is therefore not likely to be biased by known confounding factors. These findings are consistent with the hypothesis that genetic factors ac- count for most of the variation of serum $L p(a)$ in both populations.

It has indeed been established that a single gene determines a polymorphism of apo(a) which relates to serum $L p(a)$ concentration. ${ }^{2}$ Heterogeneity among populations in the distribution of alleles of the gene encoding apo(a) may therefore explain some of the observed heterogeneity in serum $\mathrm{Lp}(\mathrm{a})$ among various ethnic groups. Interestingly, variability in apo(a) size polymorphisms explained only little of the variation in serum Lp(a) in Blacks compared to other populations (0.19 in Black Sudanese but 0.41 in Tyroleans and 0.77 in Malays). ${ }^{20}$ Recent investigations at the apo(a) gene level did, however, demonstrate in Whites that the inter-individual variability in serum $\mathrm{Lp}(\mathrm{a})$ could be explained almost entirely by variation at the apo(a) locus while only a fraction was explained by the apo(a) size polymorphism. ${ }^{4,39}$ Conducting similar investigations in other ethnic groups may further strengthen the hypothesis that most of the variation of serum $\mathrm{Lp}(\mathrm{a})$ is under genetic control in all populations and help elucidate racial differences in serum $\mathrm{Lp}(\mathrm{a})$ levels.

\section{ACKNOWLEDGEMENTS}

The authors wish to thank Pharmacia/Switzerland for providing free kits for determination of serum $\mathrm{Lp}(\mathrm{a})$ concentration. 


\section{REFERENCES}

${ }^{1}$ MacLean J W, Tomlinson J E, Kuang $W J$ et al. cDNA sequence of human apolipoprotein(a) is homologous to plasminogen. Nalure 1987: 330: 132-37.

2 Utermann G. The mysteries of lipoprotein(a). Science 1989; 246: 904-10.

${ }^{3}$ Boerwinkle E, Leffer C C, Lin J, Lackner C, Chiesa G, Hobbs H H. Apo(a) gene accounis for greater than $90 \%$ of the variation in plasma Lp(a) concentrations. J Clin Invest 1992; 90: $52-60$.

${ }^{4}$ Kraft H G, Kochl S, Menzel H J, Sandholzer C, Utermann G. The apolipoprotein(a) gene: a transcribed hypervariable locus controlling plasma lipoprotein(a) concentration. Circulation 1992; 86(Suppl. 1): 1-337.

${ }^{5}$ Albers J J, Hazzard W R. Immunochemical quantification of human plasma Lp(a) lipoprotein. Lipids 1974; 9: 15-26.

${ }^{6}$ Schultz J S, Shreffler D C, Sing C F, Harvie N R. The genetics of the Lp antigen. I-Its quantification and distribution in a sample population. Ann Hum Genet 1974; 38: 39-46.

${ }^{7}$ Schriewer H, Assmann G, Sandkamp M, Schulte H. The relationship of lipoproten(a) to risk factors of coronary heart disease: initial results of the prospective epidemiological study on company employees in West falia. J Clın Chem Clin Biochem 1984; 22: $591-96$.

${ }^{8}$ Scanu A M. Lipoprotein(a): a potential bridge between the fields of atherosclerosis and thrombosis Arch Pathol Lab Med 1988; 112: $1045-48$.

${ }^{9}$ Berg K, Dahlen G, Frick M H. Lp(a) lipoprotein and pre-beta 1lipoproten in patıents with coronary heart disease. Clin Genet 1974; 6: 230-35.

${ }^{10}$ Kostner G M, Avogaro P, Cazzolato G, Marth E, Bittolo-Bon G, Bunici G B. Lipoprotein $L p(a)$ and the nsk of myocardial infarction. Atherosclerasis 1981; 33: 51-61.

11 Armstrong V W, Cremer P, Eberle E et al. The association between serum $L p(a)$ concentrations and anglographically assessed coronary atherosclerosis: dependence on serum LDL levels. Alherasclerosis 1986; 62: 249-57.

12 Hoefler G. Harnoncourt F, Paschke E, Mirti W. Pfeiffer K H, Kostner G M. Lipoprotein(a): a risk factor for myocardial infarction. Arteriosclerosts 1988; 8: 398-401

${ }^{13}$ Rhoads G G, Dahlen G, Berg K, Morton N E, Dannenberg A L. $L P(a)$ lipoprotcin as a risk factor for myocardial infarction. JAMA 1986; 256: 2540-44.

${ }^{14}$ Srinivasan S R, Dahlen G H, Jarpa R A, Webber L S, Berenson S. Racial (Black-White) differences in serum lipoprotein(a) distribution and its relation to parental myocardial infarction in children. Bogalusa Heart Study. Circulation 1991; 84: 160-67.

${ }^{15}$ Moliterno D J, Leffert C C, Lange R A et al. Plasma lipoprotein(a) is not a risk factor for coronary atherosclerosis in blacks. Circulation 1992; 86(Suppl. 1): 1-337,

${ }^{16}$ Sorrentino $M$, Vielhauer C, Fless G M, Scanu A M. Gender and lipoprotein(a) in blacks: correlation with coronary artery disease in black women but not in black men. Circulation 1992; 86(Suppl. 1): 1-337.

17 Haffner S M, Gruber K K, Morales P A et al. Lipoprotein(a) concentrations in Mexican American and non-Hispanic Whites: The San Antonio Heart Study. A $m J$ Epidemiol 1992; 136: $1060-68$.

${ }^{18}$ Guyion J R, Dahlen G H, Patsch W, Kauiz J A, Gotto A M. Relationship of plasma lipoprotein $L p(a)$ levels to race and to apolipoprotein B. Arteriosclerosis 1985; 5: 265-72.

${ }^{19}$ Parra H J, Luyeyé I, Bouramoue C, Demarquilly C, Fruchan J C. Black-white differences in serum $\mathrm{Lp}(\mathrm{a})$ lipoprotein levels. Clin Chem Acta 1987; 167: 27-31.
${ }^{20}$ Sandholzer C, Hallman D H, Saha $\mathrm{N}$ et al. Effects of the apoliprotein(a) size polymorphism on the lipoprotein(a) concentration in 7 ethnic groups Hum Genet 1991; 86: 607-14.

${ }^{21}$ Cobbaen C, Kesteloot H. Serum lipoprotein(a) levels in racially different populations. Am J Epidemiol 1992; 136: 441-49.

22 Filliot J M. Histoire des Seychelles. France: Ministere des Relations Extérieures, Cooperation et Développement, 1982.

23. Bovet P. Shamlaye C, Kitua A, Riesen W F, Paccaud F, Dariolı R. High prevalence of cardiovascular risk factors in the Seychelles (Indian Ocean). Anenosclerosis 1991: 11: 1730-36.

${ }^{24}$ Bovet P, Rosalie D, Shamlaye C. Darioli R, Paccaud F. The Seychelles Cardiovascular Disease Study. Soz Praeventivmed 1991; 36(Suppl. 1): S3-7.

${ }^{25}$ Wietlisbach V, Barazzoni F. Echantillonage et analyse de la participation pour la deuxième enquête MONICA (1988-1989) sur les facteurs de risque cardiovasculaire. Schweiz Med Wschr 1993; 12अ(Supp. 48): 13-20.

${ }^{26}$ Albers J J, Adolphson J L, Hazzard W R. Radio-immunoassay of human plasma Lp(a) hipoprotein. I Lipid Res 1977; 18: $331-38$.

27 World Health Organization. MONICA Manual CVD/MNC/Version I.I. Geneva: World Health Organization, 1986.

28 The Seychelles Cardiovascular Diseases Survey 1989. Soz Proeventivmed 1991; 361Suppl. 1): S1-\$89

${ }^{29}$ Etude MONICA-Suisse et étude báloıse sur l'altmentation. Tension arténelle, lıpıdes sanguins, habitudes tabagiques et poids corporel en Suisse: les résultats de trois enquêtes de population (1988-1990). Schweiz Med Wschr 1993; 123(Suppl. 48): I-46

${ }^{30}$ Pinn G. Bovet P. Alcohol related cardiomyopathy in the Seychelles. Med J Aust 1991; 155: 529-32.

${ }^{31}$ Tappy L. Bovet P, Shamlaye C. Prevalence of diabetes mellitus and obesity in the adult population of the Seychelles. Diab Med 1991; 8: 448-52.

32 Dahlen G, Encson C, Berg $K$ In vitro studies of the interaction of isolates Lp(a) lipoproten and other lipoprotens with glycosamınoglycans Clin Gener 1978; 14: 36-42.

${ }^{33}$ Fless G M, Rough C A, Scanu A M. Heterogeneity of human plasma lipoprotein(a). J Bıol Chem 1984; 259: 1470-78.

${ }^{34}$ Soma M, Fumagalli R, Paoletti R et al. Plasma Lp(a) concentration after oestrogen and progestagen in postmenopausal women. Lancet 1991, 337: 612.

35 Hennich J, Sandkamp M, Kokott R, Schulte H, Assmann G. Relationships of lipoprotein(a) to variables of coagulation and fibrinolysis in a healthy population. Clin Chem 1991: 37: 1950-54.

36 Dahlen G H, Guyton J, Attar M, Farmer J A, Kautz J A, Gotto A M. Association of levels of lipoprotein(a), plasma lipids, and other lipoproteins with coronary artery disease documented by angiography. Circulation 1986; 74: 758-65.

37 Albers J J, Cabana V G, Warnick G R, Hazzard W R. Lp(a) lipoprotein: relationship to sinking pre-B lipoprotein, hyperlipoproteinemia and apolipoprotein B. Melabolism 1975; 24: 1047-54

${ }^{38}$ Corsetti J P, Sterry J A, Sparks J D, Sparks C E, Weintraub M. Effect of weight loss on serum lipoprotein(a) concentrations in an obese population. Clin Chem 1991; 37: 1191-95.

39 Cohen J, Chiesa G, Hobbs H H. Apolipoprotein(a) genes of identical size are polymorphic in sequence. Circulation 1992; 86(Suppl. 1): 1-337.

(Revised version received July 1993) 